\title{
Nitrogen fertiliser replacement by single and multi-strain rhizobial inoculants for black gram, green gram and soybean cultivation in Sri Lanka
}

\author{
CS Hettiarachchi ${ }^{1 *}$, CL Abayasekara ${ }^{2}$, P Saravana Kumar ${ }^{2}$, S Rajapakse ${ }^{3}$, SA Kulasooriya ${ }^{4}$, EMHGS \\ Ekanayake $^{4}$, RKGK Kumara ${ }^{4}$ and HMAC Gunaratne ${ }^{5}$ \\ ${ }^{1}$ Department of Geography, Faculty of Arts, University of Peradeniya, Peradeniya. \\ ${ }^{2}$ Department of Botany, Faculty of Science, University of Peradeniya, Peradeniya. \\ ${ }^{3}$ Department of Molecular Biology and Biotechnology, University of Peradeniya, Peradeniya. \\ ${ }^{4}$ National Institute of Fundamental Studies, Hantana Road, Kandy. \\ ${ }^{5}$ Plenty Foods PLC, No 19, $3^{\text {rd }}$ Lane, Rathmalana.
}

Submitted: 16 June 2020; Revised: 23 November 2020; Accepted: 22 January 2021

\begin{abstract}
Various environmental, economic and health problems have arisen in the world due to the continuous application of $\mathrm{N}$-fertilisers for crop production, especially in the third world countries. The current study was undertaken to develop effective rhizobial inoculants for three major legume crops in Sri Lanka, namely Vigna mungo, Vigna radiata and Glycine max to replace the application of nitrogen fertilisers. Rhizobial isolates were obtained from the root nodules of different cultivars of edible legumes, non-edible wild legumes and wild relatives of Vigna spp. Authentication and screening for effectiveness of the isolates were carried out, and five strains were selected as effective isolates and cross inoculated with the three legumes along with a stress tolerant strain, which was previously screened. A pot experiment was followed by a field trial in the dry zone of Sri Lanka under farmers' conditions as single and multi-strain inoculations. The results of the pot experiment indicated that the addition of rhizobial inoculants increased the growth performance in all treatments. In the field trial, both single and multi-strain inoculants gave significant increases in yield, compared to $\mathrm{N}$-fertiliser application in all three crops, viz; an increase of the yield from $3 \%$ to $39 \%$ in $V$. mungo, $5 \%$ to $14 \%$ in $V$. radiata, and $4 \%$ to $13 \%$ in G. max. In conclusion, the current study has shown that single and multi-strain rhizobial inoculants are capable of completely replacing urea application to $V$. mungo, V. radiata and G. max, in Sri Lanka without any yield reduction.
\end{abstract}

Keywords: Glycine max, multi strain, N-fertiliser rhizobial inoculants, single-strain rhizobial inoculants, Vigna mungo, Vigna radiata.

\section{INTRODUCTION}

Rudimentary inoculation practices, such as moving soil from the previously cultivated fields, with well nodulated legumes, were recommended soon after Hellriegel's 1886 report on 'legumes could fix $\mathrm{N}_{2}$ '. The commercial use of pure cultures of rhizobia as inoculants was then patented in 1896 by Nobbe and Hiltner (Fred et al., 1932). Innovations in inoculant product formulations has led the establishment of inoculant manufacturing industries in Europe, North America and Australia. Despite the long history of legume inoculant use and development, only a few farmers in the developing countries of Asia have adopted inoculation into their legume cultivation practices. With time legume inoculation with rhizobia has gained importance in agricultural biotechnology (Aurora et al., 2017; Santos et al., 2019).

Examination of the legume inoculation technology identifies a potential for rapid penetration into the Asian agricultural input markets. The use of legume inoculation is inexpensive and requires little technical knowledge. The economic and environmental risk associated with inoculant use is minimal (Hettiarachchi et al., 2014). Biological nitrogen fixation by legumes is an essential important component of small-holder and low-input cropping systems commonly practiced in Asia. The

\footnotetext{
*Corresponding author (shantha@pdn.ac.lk; (DD https://:orcid.org/0000-0002-5308-8785)
} 
limited use of inoculant in Asia is not surprising because rhizobial inoculant production and marketing in many parts of Asia have been hampered by problems common to many developing countries. However, evidence is available to ascertain that many farmers could derive economic benefit by using inoculants (Ojiem et al., 2014; Chekanai et al., 2018; Rurangwa et al., 2018).

The overuse of chemical nitrogen fertilisers has caused an imbalance in the nitrogen cycle and aggravated the pollution in surface and groundwater. Increased loads of nitrogen fertiliser to freshwater and marine ecosystems have caused eutrophication (Khan et al., 2017). There is no doubt that the excessive use of chemical fertiliser and other agrochemicals is not healthy for the ecosystem, environment and human beings. Despite these problems, many farmers continue to use excessive amounts of fertilisers and toxic agrochemicals (pesticides and herbicides), with the false expectation of higher crop yield. Overuse or abuse of artificial fertilisers and other agrochemicals has increased during the last two decades and is widely used by farmers in Sri Lanka. Both the agrochemicals and petrochemicals act as environmental pollutants as well as a contributor of certain diseases, such as chronic kidney disease of unknown etiology (CKDu); a disease mainly affecting the North Central Province and spreading to other areas in Sri Lanka (Rajapakse et $a l ., 2016)$, and cancer which is prevailing in several parts of Sri Lanka. Approximately 3.5\% of the government budget is currently being spent on the agro-subsidies.

In Sri Lanka, the Rhizobial Inoculant Production Facility, initiated at the Department of Botany, University of Peradeniya which has later moved to the National Institute of Fundamental Studies (NIFS), Kandy has reported that the rhizobial inoculants prepared with ground coir dust as the carrier material, could produce high yields of soybean compared to $50 \mathrm{~kg}$ per hectare of urea (maximum level recommended by the Department of Agriculture) (Kulasooriya et al.,2017). The selling price of a $250 \mathrm{~g}$ inoculum packet recommended for use for one acre is Rs. $400(\approx \$ 2)$. The usual rate of application of urea among soybean farmers is $40 \mathrm{~kg} /$ acre and is applied in two doses; $20 \mathrm{~kg}$ as basal and $20 \mathrm{~kg}$ as a top dressing. As of current market price, this costs Rs. $4250(\approx \$ 22)$ for a farmer, in addition to the cost of Rs. $3000(\approx \$ 15)$ for 5 labourers required for the application of fertiliser. In addition, the farmer has to bear transport cost of urea from the purchasing point to his field. It has also been observed that weed growth is reduced at least by $50 \%$ in crop cultivations inoculated with rhizobial inoculants (Kulasooriya et al., 2017) compared to those fertilised with urea. A farmer could save another Rs. 4000 $(\approx \$ 20)$ per acre on the cost of agrochemicals needed for weed and pest control. Therefore, the use of the inoculants could make a total saving of Rs. $11,000(\approx \$ 55)$ per acre to a farmer compared to a field receiving the complete package of recommended agro-chemicals. The use of rhizobial inoculants produced by the NIFS is gaining popularity in Sri Lanka (Kulasooriya et al., 2017).

It is a challenge to develop a novel rhizobial inoculant that can promote higher levels of nitrogen fixation under practical field conditions. When the factors such as moisture, temperature, soil $\mathrm{pH}$ and salinity become extreme, improving yield becomes complicated (Giddens et al., 1982). Natural rhizobia of wild legumes growing under adverse conditions, such as salt stress, elevated temperatures and drought, generally exhibit higher tolerance to such conditions. The rhizobia of wild legumes in arid zones exhibit higher tolerance to prevailing adverse conditions, such as salt stress, elevated temperatures and desiccation (Zahran, 2001). Studies are needed to test the possibility of using effective strains isolated from black gram, green gram and soybean along with stress-tolerant rhizobia as inoculants to increase $\mathrm{N}$-content of these edible legumes under stress conditions and the yield. Arora et al. (2017) reported that stress tolerant rhizobial species can be incorporated in developing bioformulations that can withstand salinity, drought and high temperatures. Although research has been undertaken on these lines, only a few contributed in developing inoculants. Ahmad et al. (2013) stated that halo-tolerant, auxin producing Rhizobium strains improve osmotic stress tolerance in mung bean. Further, Tewari and Arora (2014) recorded the use of exopolysaccharides (EPS) in bioformulation, as EPS protects inoculated rhizobial cells from stress factors such as salinity, desiccation and $\mathrm{pH}$.

Multi-strain rhizobial inoculation of African Acacias under nursery conditions showed a significant increase in total nitrogen than that of the control plants in six out of the seven species (Sutherland et al., 2000). Significant increases in dry weight and total nitrogen over controls ranged from $19 \%$ to $75 \%$ and $11 \%$ to $89 \%$, respectively. On the other hand, studies conducted on common bean (Phaseolus vulgaris L.) showed that three rhizobial strains evaluated were equally effective in the accumulation of total shoot $\mathrm{N}$ and that the multistrain inoculant offered no consistent advantage over the single-strain inoculants. In the United States multistrain inoculants are produced commercially (Burton et al., 1980) to provide a compensatory mechanism to theoretically meet the constraints imposed by the host- 
strain-environment interactions, which is impossible or limited with single-strain inoculants. A very few systematic studies have been carried out to evaluate the performances of single-strain and multi-strain inoculants and limited information is available demonstrating the effects of different rhizobial strains for efficient nitrogen fixation.

There is evidence indicating that differential competition for nodule occupancy between strains of Bradyrhizobium japonicum in the presence of nitrate in sand cultures (McNeil et al., 1982). According to Somasegaran and Bohlool (1990) the nitrogen-fixing effectiveness of multistrain inoculants was found to be determined by both the effectiveness of the component strains and the percentage of the nodules occupied by them. Multistrain formulations were equally effective as most effective single-strain inoculants (Kyei-Boahen et al., 2005) or intermediate between the most and the least effective. The percentage of nodules occupied and the amount of nitrogen fixed by the component strains of a multi-strain inoculant showed highly significant linear correlation.

Black gram (Vigna mungo L. Hepper), a member of the Asian Vigna crop group is an annual pulse crop native to Central Asia. It is the staple crop in Central and south East Asia. This crop plays an important role in daily diets because of its high protein content (20-25\%), which is double of wheat and three times of rice (FAO, 1994). Green gram (Vigna radiata) seed is more palatable, nutritive, digestible and non-flatulent than other pulses grown. Its seeds contain $24.2 \%$ protein, $1.3 \%$ fat and $60.4 \%$ carbohydrates and $118 \mathrm{mg}$ and $340 \mathrm{mg}$ of calcium and phosphorous, respectively per $100 \mathrm{~g}$ of seeds. It is rich in vitamin $\mathrm{A}$ and considered as a substitute for animal protein and forms a balanced diet when used with cereals (Consideine, 1992). Soybean (Glycine max L.) is the most important grain legume crop in the world in terms of total production and international trade. Soybean seeds contain $18 \%$ to $23 \%$ oil and about $38 \%$ to $44 \%$ protein (Hymowizt et al., 1998). These three crops are the most important grain legumes cultivated in the rain fed farming systems in dry and intermediate zones of Sri Lanka.

Comparative studies between single-strain and multistrain inoculants have not been reported in Sri Lanka. A combination of effective high nitrogen fixing rhizobial strains with stress tolerant strains, if shown to be superior and applicable to a wider range of habitats, could be advantageous to any commercial inoculant producer. Therefore, the main objective of the current study was to evaluate the efficiency of single and multistrain rhizobial inoculants on black gram, green gram and soybean in Sri Lanka.

\section{METHODOLOGY}

\section{Pot experiment under semi aseptic conditions}

A pot experiment was carried out in a plant house under semi aseptic conditions, in the Department of Botany, Faculty of Science, University of Peradeniya, Sri Lanka

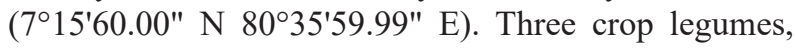
namely, Vigna mungo (black gram), Vigna radiata (mung bean) and Glycine $\max$ (soybean), were used in the study.

\section{Preparation of pots}

All the pots (black plastic: $43 \mathrm{~cm}$ diameter) were surface sterilised using bleaching powder $(4 \mathrm{~g})$ dissolved in water $(100 \mathrm{~mL})$, followed by rinsing with hot water. A rigifoam (polystyrene foam) disc of $1 \mathrm{~cm}$ thickness was placed at the bottom of a pot and filled with washed autoclaved river sand till the level of sand reached 1 inch from the top of the pot. Pots were filled with boiling water and drained 2 to 3 times to remove any soluble nitrogen present.

\section{Seed preparation and germination}

Vigna mungo, V. radiata and G. max seeds were surface sterilised separately by immersing in $70 \%$ alcohol for 1-2 min followed by rinsing 5 times with sterilised water. Seeds were planted after sterilisation. A sterilised plastic tube (diameter $1 / 2$ inch) was inserted in the middle to supply nutrients and water during the experiment. After planting of seeds the pots were covered using cling wrap prior to inoculation to prevent air borne contamination.

\section{Strain selection}

Five rhizobial strains (C8, C10, M5, M6 and VD1) isolated from different host plants (Table 1), which were previously screened (Hettiarachchi et al., 2014) as effective nitrogen fixing, and high nodulating strains along with K7 (isolated from Vigna trilobata), which was previously screened (Hettiarachchi et al., 2013) as a stress tolerant strain were used for inoculation as single and multi-strain inoculant combinations as described in 
Table 1: Rhizobial strain isolated host plant, Gene Bank accession number of rhizobial strains, rhizobia cross inoculated crop plant and different combinations of rhizobia used for treatment

\begin{tabular}{lcccc}
\hline Host Plant & $\begin{array}{c}\text { Rhizobial } \\
\text { strains }\end{array}$ & $\begin{array}{c}\text { Gene Bank } \\
\text { Accession No }\end{array}$ & $\begin{array}{c}\text { Crop } \\
\text { species }\end{array}$ & Rhizobial combinations used \\
\hline Mimosa pudica & M5 (ef) & KF008230 & V. mungo & M5VD1K7, M5VD1, M5K7, VD1K7, M5, VD1, K7 \\
Vigna dalzelliana & VD1 (ef) & KF008232 & & \\
Crotalaria brownie & C10 (ef) & KF008228 & V. radiata & C10M6K7, C10M6, C10K7, M6K7, C10, M6, K7 \\
Mimosa pudica & M6 (ef) & KF008231 & & \\
Crotalaria brownie & C8 (ef) & KF008227 & G. max & C8VD1K7, C8VD1, C8K7, VD1K7, C8, VD1, K7 \\
Vigna trilobata & K7 (st) & & & \\
\hline
\end{tabular}

* ef - effective st - stress tolerant

Table 1. Sequencing of $16 \mathrm{~S}$ rRNA region was carried out for all effective isolates and submitted to the Gene Bank and Accession numbers were obtained. For K7, DNA fingerprinting was carried out using ERIC primer.

\section{Inoculant preparation}

Single-strain rhizobial inocula were cultured separately on $1 / 2$ Lupin agar (LA) medium. The inocula were separately obtained using $1 \%$ sucrose solution and the resulting rhizobial broths were separately transferred into autoclaved beakers. Multi-strain inoculants were prepared by adding equal volumes from each singlestrain, resulting in equal volumes for each treatment.

\section{Inoculation}

After 3 days of seeding of the host plant, using a micropipette, $1 \mathrm{~mL}$ of the rhizobial inoculum was inoculated directly on the seedlings. As controls, the uninoculated and nitrogen controls were injected with $1 \mathrm{~mL}$ of distilled water. Pots were covered with sterilised gravel to prevent air borne contamination.

\section{Experimental design}

Four replicate pots were used with three plants per pot (12 plants) for each Rhizobium inoculum with nitrogen positive and negative controls. These were arranged in a complete randomised design (CRD).

\section{Plant house conditions, nutrients and watering}

Autoclaved water and nutrient solutions $(60 \mathrm{~mL}$, devoid of nitrogen) $\left(\mathrm{N}^{-}\right)$were added to all the plants on designated days of the week. In addition, $5 \mathrm{~mL}$ of $1 \% \mathrm{KNO}_{3}$ was added weekly to the nitrogen positive control $\left(\mathrm{N}^{+}\right)$plants (Master class in Rhizobial Technology, 2012).

\section{Plant and nodule assessment}

After 8 weeks, the plants were visually rated (scale of $0-10$, based on plant growth performance) and then harvested. The roots were carefully washed, and the nodules were detached, and wrapped with absorbent tissue paper and allowed to dry at room temperature. The nodules, shoots and roots were oven-dried at $70{ }^{\circ} \mathrm{C}$ for 48 $\mathrm{h}$ and weighed using an analytical balance (KeRn ABS 220-4 No. WB 1210059).

\section{Strain effectiveness}

The effectiveness of the strains was calculated using the equation below (Fernando et al., 2005). Dry mass (DM) of the strain-inoculated plant was compared with the $\mathrm{N}^{-}$ and $\mathrm{N}^{+}$controls.

$\frac{\% \text { Strain effectiveness }=[\mathrm{DM} \text { of the inoculated plant }-\mathrm{DM} \text { of the } \mathrm{N}-\text { control }] \times 100}{[\mathrm{DM} \text { of the } \mathrm{N}+\text { control }-\mathrm{DM} \text { of the } \mathrm{N}-\text { control }]}$

Field trials in the dry zone

\section{Field description}

Field trials were carried out in the dry zone with the same combinations of rhizobial inoculants, as used for the pot experiments. Vigna mungo and V. radiata fields were in Bulagala dry-zone $\left(7^{\circ} 54^{\prime} 0^{\prime \prime} \mathrm{N} 80^{\circ} 37^{\prime} 60^{\prime \prime} \mathrm{E}\right)$ and $G$. $\max$ fields were located at in Galnawa dry zone $\left(8^{\circ} 02^{\prime} 02\right.$ " N80 $\left.28^{\prime} 45^{\prime \prime} \mathrm{E}\right)$.

\section{Experimental design}

A randomised complete block design (RCBD) was used with three replicate blocks per treatment. The plot sizes were $2.74 \times 1.52 \mathrm{~m}$ for $V$. mungo, $3.66 \times 1.52 \mathrm{~m}$ for $\mathrm{V}$. radiata and $4.27 \times 1.83 \mathrm{~m}$ for G. max. The three rows of plants adjacent to the edge of each plot on all four sides were not considered when taking readings, in order to minimise the edge effect from all sides of each plot. Nitrogen positives and negatives were used as controls. 


\section{Single-strain and multi-strain rhizobial inoculum preparation}

Single and multi-strain inoculants were prepared similar to the pot experiment. Rhizobial broth cultures were injected into autoclaved, powdered and packeted coir dust (Kulasooriya et al., 2007).

\section{Seeding and agronomic practices}

Seeds were mixed with the coir dust-based inoculum and sown (Kulasooriya et al., 2008). The recommended seed requirement was used. Plots were irrigated once a week and recommended agronomic practices were applied (Table 2). Before the addition of the basal dressing the plants were thinned according to the recommendations. A basal dressing of fertiliser urea (only for the $\mathrm{N}^{+}$control), Triple Super Phosphate (TSP) and Muriate of Potash (MOP) (to all the treatments) was added 12 days after sowing. A top dressing of urea was added at flowering, only to the nitrogen positive control.

\section{Nodule and dry weight assessment}

Before harvesting (after 8 weeks), 30 plants were visually rated (scale of $0-10$, based on plant growth performance). The roots were carefully washed and the nodules were detached and wrapped with absorbent tissue paper and dried at room temperature. The nodules, shoots and roots were oven-dried at $70^{\circ} \mathrm{C}$ for $48 \mathrm{~h}$ and weighed.

\section{Yield data}

Yield and yield component data of remaining plants ( $V$. mungo $\sim 80$ plants, $V$. radiata $\sim 100$ plants and $G$. $\max \sim 200$ plants) were recorded after 80-90 days of planting.

\section{Statistical analysis}

Data on nodule number (NN), nodule dry weight (ND), shoot dry weight (SD), root dry weight (RD), total dry weight (TD), yield and yield component data were subjected to analysis of variance (ANOVA) followed by Duncan's Multiple Range Tests (DMRT) to separate the treatment means.

\section{RESULTS AND DISCUSSION}

\section{Pot experiment}

\section{Vigna mungo}

Morphological differences were observed within treatments showing variations in the effectiveness of the rhizobial treatment. The highest average visual rate (AVR) of nine was observed with multi-strain M5K7 treatment, whereas the lowest (seven) was with the $\mathrm{N}$ minus control $\left(\mathrm{N}^{-}\right.$control) and rest of the treatments showed a value of eight (Supplementary Table 1). A significant increase in nodulation (ANN) and nodule dry weight (AND) was observed with the multi-strain M5K7 compared to the rest of the treatments. All the rhizobial inoculated treatments, including the $\mathrm{N}+$ control, showed no significant difference in average shoot dry weight (ASD), Average Root Dry weight (ARD) and total dry matter production. These values were significantly higher than the $\mathrm{N}^{-}$control.

\section{Vigna radiata}

Single-strain C10 showed the highest value for AVR (nine), ANN, AND, ASD and ARD (Supplementary Table 2). When considering the total dry matter production, single-strain $\mathrm{C} 10$ gave the highest value, which was not significantly different from the value obtained by $\mathrm{K} 7$ treatment.

\section{Glycine max}

Multi-strain VD1K7 showed the highest value (nine) and the N- showed the lowest value (six) with respect to AVR. With respect to ANN, AND, ASD, ARD and total dry weight, multi-strain VD1K7 gave significantly higher values than all other treatments (Supplementary Table 3).

Table 2: Seedling and agronomic practices: requirements, recommendations

\begin{tabular}{|c|c|c|c|c|}
\hline Host Plant & $\begin{array}{c}\text { Seed } \\
\text { requirement }\end{array}$ & $\begin{array}{l}\text { Spacing between } \\
\text { plants }\end{array}$ & $\begin{array}{l}\text { Basal fertiliser } \\
(\mathrm{kg} / \mathrm{h})\end{array}$ & $\begin{array}{c}\text { Top dressing } \\
\text { (only to } \mathrm{N}+\text { control) }\end{array}$ \\
\hline V. mungo & $30 \mathrm{~kg} / \mathrm{ha}$ & $40 \mathrm{~cm} \times 10 \mathrm{~cm}$ & $\begin{array}{c}\text { TSP } 100, \text { MOP } 75, \\
\text { Urea } 30 \text { (only to N+ control) }\end{array}$ & Urea $35 \mathrm{~kg} / \mathrm{h}$ \\
\hline V. radiata & $30 \mathrm{~kg} / \mathrm{ha}$ & $40 \mathrm{~cm} \times 10 \mathrm{~cm}$ & $\begin{array}{c}\text { TSP } 100, \text { MOP } 75, \\
\text { Urea } 30 \text { (only to } \mathrm{N}+\text { control) }\end{array}$ & Urea $35 \mathrm{~kg} / \mathrm{h}$ \\
\hline G. $\max$ & $55 \mathrm{~kg} / \mathrm{ha}$ & $40 \mathrm{~cm} \times 5 \mathrm{~cm}$ & $\begin{array}{c}\text { TSP } 150, \text { MOP } 75, \\
\text { Urea } 50 \text { (only to } \mathrm{N}+\text { control) }\end{array}$ & Urea $50 \mathrm{~kg} / \mathrm{h}$ \\
\hline
\end{tabular}


The Strain Effectiveness (SE) values indicated that all the treatments resulted in a high level of effectiveness in Vigna mungo (Table 3), according to Beck et al. (1993). $\mathrm{SE}$ values of the isolates were rated as highly effective $(>80 \%)$, effective $(50-80 \%)$ and ineffective $(<35 \%)$. Vigna radiata $\mathrm{SE}$ values showed that other than three treatments, all other treatments had high effectiveness. With regards to G. $\max$, except C8VD1K7 treatment, all other treatments showed high effectiveness.

The pot experiment was mainly done in order to evaluate the infective ability of the single-strain (SS) and multi strain (MS) inoculants. All the tested inoculants produced nodules in the three crops under investigation. There was no nodulation in the uninoculated controls in the pot experiment, demonstrating that aseptic conditions were met in the experimental set up and maintenance of the plants in the greenhouse was adequate (Bala et al., 2003). Overall, the multi-strain inoculants produced more nodules than the single-strain inoculants in the pot experiments

Similar to previous studies, host biomass production in the pot experiment was used as the criterion for strain effectiveness in $\mathrm{N}_{2}$ fixation. Compared to $\mathrm{N}^{-}$application, in all three crops, dry weights increased in inoculated treatments. Hoben (1994) and Peoples et al. (2002) explained that shoot dry matter is a good indicator of relative isolate effectiveness. The current results show that the same or higher dry matter could be obtained by rhizobial inoculation without adding $\mathrm{N}$ fertilisers.

\section{Field trial}

The pot experiments were conducted under aseptic conditions in a greenhouse whereas in the field trials, the inoculant strains had to compete with the indigenous rhizobia and other indigenous microbes present in the soil. Although some strains are effective in $\mathrm{N}_{2}$ fixation, they may not be able to compete with the indigenous rhizobia and other soil microorganisms for substrates and space in most locations (Santos et al., 2019). Also, the naturally occurring rhizobium populations often occur in high numbers in soil and can compete strongly with the introduced rhizobium inoculants. Better $\mathrm{N}_{2}$ fixation can be achieved by selecting superior rhizobia. However, the selection of these rhizobia would need to take into consideration not only their $\mathrm{N}_{2}$ fixing capacity but also the competitive ability against native rhizobia, which are frequently ineffective in $\mathrm{N}_{2}$ fixation (Hettiarachchi et al., 2014). Superior $\mathrm{N}_{2}$-fixing strains have to outcompete native rhizobia and occupy a significant proportion in nodules. For this to be achieved, rhizobia have to be selected under natural conditions in competition with the native rhizobia (Rengel, 2002) emphasizing the necessity of conducting a field trial.

\section{Plant growth parameters}

\section{Vigna mungo}

With respect to AVR values, single-strain VD1 and multistrain M5K7 gave the highest value (nine), whereas the rest of the treatments gave a similar value (eight). With respect to ANN, multi-strain M5VD1K7 and K7 gave significantly higher values than both $\mathrm{N}$ controls. When considering the AND values, M5VD1K7 and M5VD1 gave significantly higher values than the $\mathrm{N}$ controls (Supplementary Table 4). Multi-strain M5K7 gave a significantly higher ASD value than the $\mathrm{N}$ controls. When looking at the ARD values, no significant difference was observed within the treatments, whereas multi-strain M5K7 and single-strain VD1 gave the highest values. Although the multi-strain M5K7 and the single-strain

Table 3: Percentage strain effectiveness (SE) based on total dry matter production of the targeted legume crops in comparison with ${ }^{\mathrm{N}+}$ and ${ }^{\mathrm{N}-}$ controls (pot experiment).

\begin{tabular}{lclrlr}
\hline \multicolumn{2}{c}{ V. mungo } & \multicolumn{2}{c}{ V. radiata } & \multicolumn{2}{c}{ G. max } \\
Strain & \%SE & \multicolumn{1}{c}{ Strain } & \%SE & \multicolumn{1}{c}{ Strain } & \%SE \\
\hline M5VD1K7 & 95.71 & C10M6K7 & 91.37 & C8VD1K7 & 39.53 \\
M5VD1 & 114.87 & C10M6 & 19.32 & C8K7 & 198.97 \\
M5K7 & 148.58 & C10K7 & 116.87 & C8VD1 & 126.27 \\
VD1K7 & 95.22 & M6K7 & 26.67 & VD1K7 & 462.18 \\
M5 & 89.29 & C10 & 245.49 & C8 & 93.84 \\
VD1 & 103.36 & M6 & 72.83 & VD1 & 219.08 \\
K7 & 106.28 & K7 & 172.16 & K7 & 198.91 \\
N+ & 100 & N+ & 100 & N+ & 100 \\
N - & 0 & N- & 0 & N- & 0 \\
\hline
\end{tabular}


VD1 gave comparatively higher values with respect to total dry matter production, no significant difference was observed within the treatments.

\section{Vigna radiata}

Except the multi-strain C10M6, the rest of the rhizobial strain inoculated treatments gave higher AVR values than both $\mathrm{N}$ controls, in which multi-strain C10M6K7, C10K7 and M6K7 and single-strain M6 gave the highest value of nine (Supplementary Table 5). Multi-strain C10M6K7 gave the highest values for both ANN and AND, which were significantly higher than both $\mathrm{N}$ controls. Multistrain $\mathrm{C} 10 \mathrm{~K} 7$ gave the highest value for ASD and ARD and is again significantly higher than both $\mathrm{N}$ controls. No significant difference was observed in the total dry matter production, in which multi-strains $\mathrm{C} 10 \mathrm{M} 6 \mathrm{~K} 7$ and C10K7 gave the highest values.

\section{Glycine max}

In G. max, multi-strain C8K7 and single-strain VD1 gave the highest values for AVR ( 9 and 8.5 respectively). Multistrain VD1K7 gave the highest value for ANN, which was significantly higher than the rest of the treatments (Supplementary Table 6). Some of the rhizobial strain inoculated treatments gave significantly higher values than both controls with respect to AND values. Only the multi-strain $\mathrm{C} 8 \mathrm{~K} 7$ gave significantly higher values for ASD, ARD and total dry matter production than the rest of the treatments. Others showed significantly similar values.

In the current study, differences in Average Number of Nodules (ANN) were observed for the same treatment in the pot and field experiments. ANN results showed that only two rhizobial inoculants gave lower values than the control values, indicating that these were not able to compete with the native soil rhizobial population. Similar to the previous field trials, with $\mathrm{N}^{+}$treatment, only a few number of nodules were observed indicating the negative effect of nitrogen fertiliser application on nodulation of the legume plants (Crews et al., 2004; Xuan et al., 2017). Nodule dry weight is essential in strain evaluation, as it serves as an indicator for symbiotic efficiency (Graham et al., 2004).

With reference to AVR values, most of the time, multi- strain inoculants were superior to the single-strain inoculants in both pot and field experiments. This could be attributed to the multi-strain's ability to effectively nodulate and enhance solubilisation of other essential soil minerals, such as phosphorus (Koskey et al., 2017). The rhizobial strain inoculated treatments always showed higher AVR values compared to the $\mathrm{N}^{-}$control. In some instances, even higher than the $\mathrm{N}^{+}$control. Since AVR values correlate with other growth and yield parameters investigated, it was found that the growth performance has increased with the addition of both single-strain and multi-strain rhizobial inoculants. Zablotowicz et al. (1991) found that increasing rhizobial diversity enhances the shoot dry weight in bean plants. In some trials, there were no significant differences among single-strain and multi strain treatments with respect to the total dry matter production. When considering the infectivity and effectivity in these inoculants with respect to the pot experiment, in $V$. mungo although the infectivity varied within the inoculants the effectivity was fairly high in all the inoculants. In $V$. radiata one single-strain inoculant and in G. max one multi strain inoculant showed high infectivity as well as high effectivity. In the field trial, in $V$. mungo both single-strain and multi strain inoculants seems to be effective. In $V$. radiata although the singlestrain inoculant performed better in the pot experiment, the multi strain inoculants performed better in the field trial. With respect to G. $\max$ the multi strain inoculants seem to be better than the single-strain inoculants. A proper combination of different infective and effective Rhizobium strains could enhance nodule, occupancy hence biological fixation of nitrogen. Hungria et al. (2000) noted that a combination of specific rhizobia strains, performs better in promoting N-fixation and growth of different bean cultivars as compared to the use of individual rhizobia strains. These results support the claims made by Kawaka et al. (2014) Korir et al., (2017) and Koskey et al. (2017), that there is a direct association among nodulation, plant growth and nitrogen accumulation in legume plants.

\section{Yield data}

\section{Vigna mungo}

Multi-strain M5K7 and the single-strain VD1 gave significantly higher NP values compared to the $\mathrm{N}^{+}$ treatment (Table 4). Most of the rhizobial strain inoculated treatments other than M5 gave significantly higher PL values than the $\mathrm{N}^{-}$control. Although the values were not significantly higher, most of the rhizobial strain inoculated treatments gave higher number of seeds per pod than both controls. All the rhizobial strain inoculated treatments gave a higher yield than both controls $\left(\mathrm{N}^{+}\right.$and $\mathrm{N}^{-}$). Significantly higher yield values were obtained from multi-strains M5VD1 and M5K7, and single-strains VD1 and $\mathrm{K} 7$. 


\section{Vigna radiata}

Other than $\mathrm{C} 10$, all other rhizobial strain inoculated treatments gave significantly higher values than both controls with respect to NP values (Table 4). When considering PL values, only multi-strain M6K7 and the single-strain K7 showed significantly higher values than the $\mathrm{N}^{-}$control. When considering the seed yield, all except single-strain $\mathrm{C} 10$ gave numerically higher values than the $\mathrm{N}^{+}$control. However, only the multi-strain $\mathrm{C} 10 \mathrm{~K} 7$ and single-strain $\mathrm{K} 7$ gave statistically significant higher values.

\section{Glycine max}

All the treatments gave significantly higher values than the $\mathrm{N}$ - control with respect to NP values, among which multi-strains $\mathrm{C} 8 \mathrm{~K} 7$ and VD1K7 gave significantly higher values (Table 4). With respect to PL all the treatments gave similar values, which were significantly higher than the $\mathrm{N}^{-}$control. The multi-strain $\mathrm{C} 8 \mathrm{~K} 7$ showed a significantly higher number of seeds/pods than the rest of the treatments. All the treatments showed significantly higher value than the $\mathrm{N}$ - control, with respect to 100 seed weight.

Table 4: Yield and yield component data

\begin{tabular}{|c|c|c|c|c|c|c|}
\hline Strain & NP & $\mathrm{PL}(\mathrm{cm})$ & $\begin{array}{c}\text { No. seeds } \\
\text { per Pod }\end{array}$ & $\begin{array}{c}100 \text { seed } \\
\text { weight }(\mathrm{g})\end{array}$ & $\begin{array}{l}\text { Seed yield } \\
\text { /plant (g) }\end{array}$ & $\begin{array}{c}\text { Estimated } \\
\text { seed yield } \\
(\mathrm{kg} / \mathrm{ha})\end{array}$ \\
\hline \multicolumn{7}{|l|}{ A) $V$. mungo } \\
\hline M5VD1K7 & $32.71^{\mathrm{bc}}$ & $4.74^{\mathrm{a}}$ & $7.10^{\mathrm{a}}$ & $4.78^{\mathrm{ab}}$ & $9.25^{\mathrm{c}}$ & $2398.25^{\mathrm{c}}$ \\
\hline M5VD1 & $39.29^{\mathrm{ab}}$ & $4.85^{\mathrm{a}}$ & $7.20^{\mathrm{a}}$ & $5.41^{\mathrm{a}}$ & $11.96^{\mathrm{a}}$ & $3101.44^{\mathrm{a}}$ \\
\hline M5K7 & $41.43^{\mathrm{a}}$ & $5.17^{\mathrm{a}}$ & $7.21^{\mathrm{a}}$ & $4.99^{\mathrm{ab}}$ & $11.05^{\mathrm{a}}$ & $2864.92^{\mathrm{a}}$ \\
\hline VD1K7 & $36.86^{\mathrm{ab}}$ & $5.04^{\mathrm{a}}$ & $7.12^{\mathrm{a}}$ & $4.55^{\mathrm{ab}}$ & $9.43^{\mathrm{b}}$ & $2444.50^{\mathrm{b}}$ \\
\hline VD1 & $41.14^{\mathrm{a}}$ & $5.13^{\mathrm{a}}$ & $6.34^{\mathrm{ab}}$ & $5.61^{\mathrm{a}}$ & $11.48^{\mathrm{a}}$ & $2976.22^{\mathrm{a}}$ \\
\hline M5 & $32.29^{\mathrm{bc}}$ & $4.40^{\mathrm{ab}}$ & $7.50^{\mathrm{a}}$ & $4.42^{\mathrm{ab}}$ & $8.82^{\mathrm{c}}$ & $2285.81^{\mathrm{c}}$ \\
\hline K7 & $36.00^{\mathrm{b}}$ & $5.089^{\mathrm{a}}$ & $7.45^{\mathrm{a}}$ & $4.92^{\mathrm{ab}}$ & $10.72^{\mathrm{a}}$ & $2779.86^{\mathrm{a}}$ \\
\hline $\mathrm{N}+$ & $31.56^{\mathrm{bc}}$ & $4.74^{\mathrm{a}}$ & $6.58^{\mathrm{ab}}$ & $4.13^{\mathrm{b}}$ & $8.56^{\mathrm{c}}$ & $2218.82^{c}$ \\
\hline $\mathrm{N}-$ & $28.11^{\mathrm{c}}$ & $4.23^{\mathrm{b}}$ & $6.17^{\mathrm{ab}}$ & $3.93^{b}$ & $7.48^{\mathrm{d}}$ & $1938.53^{\mathrm{d}}$ \\
\hline \multicolumn{7}{|l|}{ B) $V$. radiata } \\
\hline C10M6K7 & $21.86^{\mathrm{ab}}$ & $7.06^{\mathrm{ab}}$ & $7.25^{\mathrm{ab}}$ & $5.57^{\mathrm{a}}$ & $8.73^{\mathrm{ab}}$ & $2183.00^{\mathrm{ab}}$ \\
\hline C10M6 & $21.29^{\mathrm{ab}}$ & $7.05^{\mathrm{ab}}$ & $6.44^{\mathrm{b}}$ & $5.00^{\mathrm{ab}}$ & $8.43^{\mathrm{ab}}$ & $2108.82^{\mathrm{ab}}$ \\
\hline C10K7 & $22.63^{\mathrm{ab}}$ & $6.89^{\mathrm{ab}}$ & $6.22^{\mathrm{b}}$ & $5.41^{\mathrm{a}}$ & $9.01^{\mathrm{a}}$ & $2252.00^{\mathrm{a}}$ \\
\hline M6K7 & $21.37^{\mathrm{ab}}$ & $7.87^{\mathrm{a}}$ & $8.45^{\mathrm{a}}$ & $5.03^{\mathrm{ab}}$ & $8.58^{\mathrm{ab}}$ & $2144.60^{\mathrm{ab}}$ \\
\hline $\mathrm{C} 10$ & $20.14^{\mathrm{bc}}$ & $6.03^{\mathrm{b}}$ & $6.57^{\mathrm{b}}$ & $4.51^{\mathrm{b}}$ & $7.74^{\mathrm{bc}}$ & $1935.00^{\mathrm{bc}}$ \\
\hline M6 & $22.71^{\mathrm{a}}$ & $6.66^{\mathrm{ab}}$ & $6.68^{\mathrm{b}}$ & $5.00^{\mathrm{ab}}$ & $8.44^{\mathrm{ab}}$ & $2109.18^{\mathrm{ab}}$ \\
\hline K7 & $22.29^{\mathrm{ab}}$ & $7.68^{\mathrm{a}}$ & $7.60^{\mathrm{a}}$ & $5.87^{\mathrm{a}}$ & $9.21^{\mathrm{a}}$ & $2303.73^{a}$ \\
\hline $\mathrm{N}+$ & $19.67^{\mathrm{c}}$ & $7.12^{\mathrm{ab}}$ & $8.01^{\mathrm{a}}$ & $4.40^{\mathrm{b}}$ & $8.02^{\mathrm{bc}}$ & $2006.00^{\mathrm{bc}}$ \\
\hline N- & $17.44^{\mathrm{d}}$ & $6.57^{b}$ & $6.52^{\mathrm{b}}$ & $3.51^{\mathrm{c}}$ & $6.80^{\mathrm{d}}$ & $1699.50^{\mathrm{d}}$ \\
\hline \multicolumn{7}{|l|}{ C) G.max } \\
\hline C8VD1K7 & $49.33^{\mathrm{c}}$ & $3.25^{\mathrm{a}}$ & $2.10^{\mathrm{c}}$ & $14.45^{\mathrm{ab}}$ & $16.64^{\mathrm{e}}$ & $4402.80^{\mathrm{e}}$ \\
\hline C8VD1 & $47.22^{\mathrm{d}}$ & $3.24^{\mathrm{a}}$ & $2.19^{\mathrm{a}}$ & $14.95^{\mathrm{ab}}$ & $16.86^{\mathrm{e}}$ & $4459.55^{\mathrm{e}}$ \\
\hline C8K7 & $62.66^{\mathrm{a}}$ & $3.03^{\mathrm{a}}$ & $2.18^{\mathrm{a}}$ & $16.92^{\mathrm{a}}$ & $20.42^{\mathrm{a}}$ & $5401.56^{\mathrm{a}}$ \\
\hline VD1K7 & $60.22^{\mathrm{a}}$ & $3.24^{\mathrm{a}}$ & $2.10^{c}$ & $16.37^{a}$ & $20.31^{\mathrm{a}}$ & $5373.60^{\mathrm{a}}$ \\
\hline $\mathrm{C} 8$ & $57.77^{\mathrm{b}}$ & $3.10^{\mathrm{a}}$ & $2.10^{\mathrm{c}}$ & $16.04^{\mathrm{a}}$ & $18.94^{b}$ & $5011.32^{\mathrm{b}}$ \\
\hline VD1 & $52.77^{\mathrm{bc}}$ & $3.13^{\mathrm{a}}$ & $2.05^{\mathrm{d}}$ & $15.91^{\mathrm{a}}$ & $17.63^{d}$ & $4663.47^{\mathrm{d}}$ \\
\hline K7 & $50.75^{\mathrm{c}}$ & $3.11^{\mathrm{a}}$ & $2.15^{\mathrm{b}}$ & $15.98^{\mathrm{a}}$ & $18.84^{b}$ & $4985.03^{b}$ \\
\hline $\mathrm{N}+$ & $55.00^{\mathrm{b}}$ & $3.03^{\mathrm{a}}$ & $2.11^{\mathrm{c}}$ & $15.03^{\mathrm{ab}}$ & $18.07^{\mathrm{cd}}$ & $4779.52^{\mathrm{cd}}$ \\
\hline N- & $44.29^{\mathrm{e}}$ & $2.10^{\mathrm{b}}$ & $2.03^{\mathrm{d}}$ & $13.07^{\mathrm{C}}$ & $14.60^{\mathrm{f}}$ & $3859.89^{\mathrm{f}}$ \\
\hline
\end{tabular}

$\mathrm{NP}=$ Average number of pods; $\mathrm{PL}=$ average pod length values in the same column [separately for sections A), B) and C)] followed by the same letter are not significantly different at $5 \%$ probability level. 
Multi-strain C8K7 and VD1K7, and single-strain C8 and K7 gave significantly higher yield values compared to the $\mathrm{N}^{+}$control.

Comparison of yield performance considering all three crops investigated under inoculation with fertiliser applications ascertains that certain strains (both single and multi) had given higher responses for the three crops tested. For $V$. mungo, all the inoculants gave higher values than the $\mathrm{N}^{+}$fertiliser application in which two multi strain inoculants (M5VD1 and M5K7) and two SS inoculants (VD1 and K7) gave comparatively higher values than the $\mathrm{N}^{+}$fertiliser application. In $V$. radiata, only one single-strain inoculant (VD1) gave a lower value than $\mathrm{N}^{+}$fertiliser application. In G. $\max$, two multi-strain inoculants (M5VD1K7 and M5VD1) and one single-strain inoculant gave a lower value than $\mathrm{N}^{+}$ fertiliser application (Figure 1).

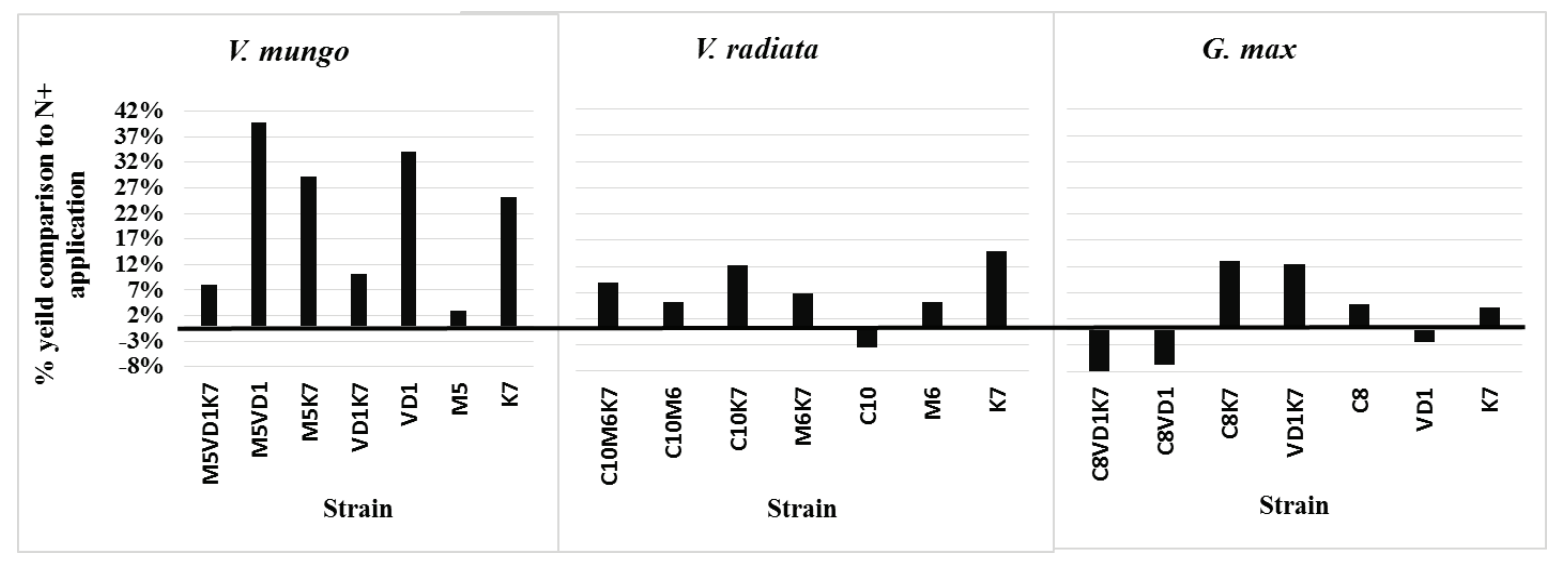

Figure 1: Percentage yield increase/decrease in comparison to $\mathrm{N}^{+}$fertiliser application (zero line indicates $\mathrm{N}^{+}$fertilizer)

According to the results obtained, both the single-strain and multi-strain inoculants are capable of completely replacing $\mathrm{N}^{-}$fertiliser application. However, multi-strain inoculants seem to be superior to single-strain inoculants (Figure 2).

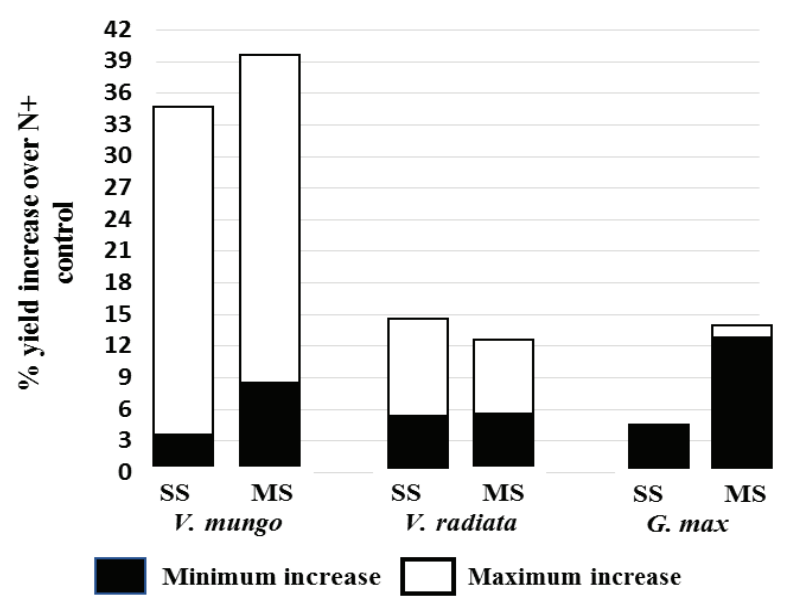

Figure 2: Yield comparison between single-strain and multi strain rhizobial inoculants
In Australia, in early studies with rhizobial inoculation, only single-strain inoculants were used as inoculants to prevent possible dominance and antagonistic effects of a particular strain in the mixture (Schwinghamer et al., 1979) to diagnose loss of effectiveness, and to facilitate quality control (Thompson et al., 1980). However, in the United States, multi strain inoculants were produced commercially (Burton et al., 1980) to provide a compensatory mechanism to theoretically meet the constraints imposed by the host-strain-environment interactions, which is impossible with single-strain inoculants.

Unlike many free-living diazotrophs, rhizobia are able to exhibit highly efficient nitrogen fixation, only when they are in the host nodule cells in endosymbiotic form as bacteroid (Hakoyama et al., 2009). Rhizobial nitrogenfixing activity is restricted to symbiotic bacteroids, and free-living rhizobia do not fix atmospheric nitrogen, a feature unique to legume/rhizobium symbiosis (Kneip et al., 2007). 
It appears that the effectiveness of mixed inoculants is dependent on the effectiveness and competitiveness of the strains in the mixture. Although much work has been documented in rhizobial ecology in evaluating the success of inoculant strains (measured as percent nodule occupancy) in numerous competition experiments, meaningful interpretations of nodule occupancies in relation to the nitrogen fixed by the nodule occupants have apparently not been quantified. Furthermore, it is noted that little information has been reported on rhizobial inoculants in the past decade (Aurora et al., 2017) and this limits a thorough discussion on this area of study.

Alhough the increase of nodulation through rhizobial inoculation resulted in elevated growth performances and enhanced yield, multi locational field testing over two or more seasons is needed before these inoculants are recommended for farmer use. Santos et al. (2019) states that farmers are more receptive to use of inoculants due to high-quality products and the availability of multistrains, which cost less than chemical fertilisers. In the context of sustainable agriculture, microbial inoculants play a major role to alleviate the negative environmental impact caused by chemical fertilisers (Santos et al., 2019).

\section{CONCLUSIONS}

In conclusion, the current study has shown that the addition of rhizobial inoculants, both single-strain and multi-strain has completely replaced urea applications to $V$. mungo, V. radiata and G. max crop cultivation in Sri Lanka while increasing the yields of all three crops investigated, significantly.

\section{Acknowledgements}

National Science Foundation of Sri Lanka (Research grant no. RG/ 2008/SUNR/01) and the National Research Council of Sri Lanka (Research grant no. NRC 11-121) gratefully acknowledged for their financial assistance.

\section{REFERENCES}

Ahmad M., Zahir Z.A. \& Nazli F. (2013). Effectiveness of halotolerant, auxin producing Pseudomonas and Rhizobium strains to improve osmotic stress tolerance in mung bean (Vigna radiata L.). Brazilian Journal of Microbiology 44(4): 1341-1348.

DOI: https://doi.org/10.1590/S1517-83822013000400045

Arora N.K., Verma M. \& Mishra J. (2017). Rhizobial bioformulations: past, present and future. In:Microorganisms for Sustainability (ed. S. Mehnaz), pp. 69-75. Springer Nature Singapore Pte Ltd., Singapore.

DOI: https://doi.org/10.1007/978-981-10-4862-3_4

Bala A., Murphy P. \& Giller K.E. (2003). Distribution and diversity of rhizobia nodulating agroforestry legumes in soils from three continents in the tropics. Molecular Ecology 12(4): 917-930.

DOI: https://doi.org/10.1046/j.1365-294X.2003.01754.x

Beck D.P., Materon L.A. \& Afandi F. (1993). Practical Rhizobium sp. Legume Technology Manual, pp. 1-54. International Center for Agricultural Research in the Dry Areas (ICARDA), Aleppo, Syria.

Burton J.C. \& Martinez C.J. (1980). Rhizobial Inoculants for Various Leguminous Species. Nitragin Company Technology Bulletine. No. 101. Nitragin Co., Milwaukee, Wisconsin, USA.

Chekanai V., Chikowo R. \& Vanlauwe B. (2018). Response of common bean (Phaseolus vulgaris L.) to nitrogen, phosphorus and rhizobia inoculation across variable soils in Zimbabwe. Agriculture, Ecosystems \& Environment 266(01): 167-173.

DOI: https://doi.org/10.1016/j.agee.2018.08.010

Consideine M. (1992). Effect of urea on photosynthesis and yield in Mung bean. Journal of Agronomy and Crop Science 168(01): 91-94.

DOI:https://doi.org/10.1111/j.1439-037X.1992.tb00983.x

Crews T.E. \& Peoples M.B. (2004). Legumes versus fertilizer sources of nitrogen: ecological trade-offs and human needs. Agriculture, Ecosystems and Environment 102(3): 279297.

DOI: https://doi.org/10.1016/j.agee.2003.09.018

FAO (1983). Technical Hand Book on Symbiotic Nitrogen Fixation: Legume-Rhizobium, pp. 3-4. The Food \& Agricultural Organization of the United Nations, Rome, Italy.

Fernando G.A. (2005). The rhizobia nodulating shrubs for revegetation of arid lands: isolation of native strains and specificity of the plant - rhizobia interaction by cross inoculation tests. Arid Land Research and Management 19(01): 307-326. DOI: https://doi.org/10.1080/15324980500299649

Fred E.B., Baldwin I.L. \& McCoy E. (1932). Root Nodule Bacteria and Leguminous Plants, pp. 343. University of Wisconsin Press, Madison, WI, USA.

Giddens J. E., Dunigan E.P. \& Weaver R.W. (1982). Legume inoculation in the Southeastern U.S.A. The University of Georgia, College of Agriculture Experimental Station Southern Cooperative Service Bulletin 283: 1-38.

Graham P.H., Hungria M. \& Tlusty B. (2004). Breeding for better nitrogen fixation in grain legumes: where do the rhizobia fit in? Crop Management Review 3(1): 1-6. DOI: https://doi.org/10.1094/CM-2004-0301-02-RV

Hakoyama T. et al., (19 authors) (2009). Host plant genome overcomes the lack of a bacterial gene for symbiotic nitrogen fixation. Nature 462: 514-517.

DOI: https://doi.org/10.1038/nature08594

Hellriegel H. \& Wilfarth H. (1886). Erfolgt die assimilation des freien Stick \& offs durch die Leguminose nunter 
Mitwirkung Niederer Organismen. Berichte der Deutschen Botanischen Gesellschaft 7: 138-143.

Hettiarachchi C.S., Abayasekara C.L., Rajapakse S., Kulasooriya S.A. \& Saravana Kumar P. (2013). Screening of stress tolerant rhizobial isolates from wild legumes growing in the southern coastal region of Sri Lanka. Proceedings of the $33^{\text {rd }}$ Annual Sessions of the Institute of Biology, Sri Lanka. Colombo, Sri Lanka, September, pp. 49.

Hettiarachchi C.S., Kumar P.S., Abayasekara C.L., Rajapakse S., Kulasooriya S.A., Ekanayake E.M.H.G.S. \& Kosala R.K.G.K. (2014). Response of Glycine max to inoculation with rhizobial strains isolated from crop wild relatives of Vigna spp., Crotalaria spp. and Mimosa spp. Jaffna University International Research Conference (JUICE) Full Paper Proceedings publications. Jaffna University, Jaffna, Sri Lanka. March, pp. 258-262.

Hettiarachchi C.S., Abayasekara C.L., Kumar P.S., Rajapakse S., Kulasooriya S.A., Ekanayake E.M.H.G.S. Kosala, R.K.G.K. \& Gunaratna H.M.A.C. (2014). Single-strain and multi-strain rhizobial inoculants for black gram (Vigna mungo) cultivation. Proceedings of the Postgraduate Institute of Science, Research Congress (PIGS). University of Peradeniya, Sri Lanka, 10-11 October, pp. 18.

Hoben H.J., Somasegara, P., Boonkerd N. \& Gaur Y.D. (1994). Polyclonal antisera production by immunization with mixed cell antigens of different rhizobial species. World Journal of Microbiology and Biotechnology 10: 538-542. DOI: https://doi.org/10.1007/BF00367662

Hungria M., Andrade D.S., Chueire L.M.O., Probanza A., Guttierrez-Mañero F.J. \& Megías M. (2000). Isolation and characterization of new efficient and competitive bean (Phaseolus vulgaris L.) rhizobia from Brazil. Soil Biology and Biochemistry 32(11-12): 1515-1528.

DOI: https://doi.org/10.1016/S0038-0717(00)00063-8

Hymowitz T., Singh R.J. \& Kollipara K.P. (1998). The genomes of the Glycine. In: Plant Breeding Reviews (ed. J. Janick), pp. 289-311. Wiely Online Library.

DOI: https://doi.org/10.1002/9780470650110.ch8

Kawaka F., Dida M. M., Opala P.A., Ombori O., Maingi J., Osoro N. \& Muoma J. (2014). Symbiotic efficiency of native rhizobia nodulating common bean (Phaseolus vulgaris L.) in soils of Western Kenya. International Scholarly Research Notices 2014(1): 1-8.

DOI: https://doi.org/10.1155/2014/258497

Kyei-Boahen S., Nleya T., Hynes R., \& Walley F.L. (2005). Single and multistrain rhizobial inocula for pinto and black bean cultivars. Journal of Plant Nutrition 28(10): 16791692.

DOI: https://doi.org/10.1080/01904160500250664

Khan M.N., Mobin M. \& Abbas Z.K. (2017). Fertilizers and their contaminants in soils, surface and groundwater. Earth Systems and Environmental Sciences 5: 225-240. DOI: https://doi.org/10.1016/B978-0-12-809665-9.098888

Kneip C., Lockhart P., Voß C. \& Maier U.G. (2007). Nitrogen fixation in eukaryotes - new models for symbiosis. $B M C$ Evolutionary Biology 7: 55-66.

DOI: https://doi.org/10.1186/1471-2148-7-55
Korir H., Mungai N. W., Thuita M., Hamba Y. \& Masso C. (2017). Co-inoculation effect of rhizobia and plant growth promoting rhizobacteria on common bean growth in a low phosphorus soil. Frontiers in Plant Science 8:141. DOI: https://doi.org/10.3389/fpls.2017.00141.

Koskey G., Mburu S.W., Njeru E.M., Kimiti J.M., Ombori O. \& Maingi J.M. (2017). Potential of native rhizobia in enhancing nitrogen fixation and yields of climbing beans (Phaseolus vulgaris L.) in contrasting environments of Eastern Kenya. Frontiers in Plant Science 8: 443. DOI: https://doi.org/10.3389/fpls.2017.00443

Kulasooriya S.A., Seneviratne G. \& Ekanayake E.M.H.G. S. (2017). Soil microbial diversity and its utilization in agriculture in Sri Lanka. In: Microbial Biotechnology, Applications, Agriculture and Environment (eds J. K. Patra, C. N. Vishnuprasad \& G Das), pp. 203-224. Springer Nature Publishers, Singapore.

DOI: https://doi.org/10.1007/978-981-10-6847-8_9

Kulasooriya S.A. (2008). Biological Nitrogen Fixation: Fundamentals and Utilization. Peradeniya Science Publication No 27. pp. 1-143. Science Education Unit, Faculty of Science, University of Peradeniya, Sri Lanka.

Kulasooriya S.A., Ekanayake E.M.H.G.S. \& Kosala Kumara, R.K.G. (2007). Application of Rhizobial Inoculants for Pulse Crop Cultivation in Sri Lanka. Workshop on Agricultural Technologies, Council for Agricultural Research Policy May 20, CARP Headquarters, Colombo, Sri Lanka.

Kyei-Boahen S., Nleya T., Hynes R.K. \& Walley F.L. (2005). Single and multi-strain rhizobial inocula for pinto and black bean cultivars. Journal of Plant Nutrition 28(10):16791692.

DOI: https://doi.org/10.1080/01904160500250664.

Master class in rhizobial technology (2012). The Isolation, Identification and Utilization of Root Nodule Bacteria (rhizobia) in Promoting Sustainable Agricultural Productivity. Institute of Fundamental Studies Kandy, Sri Lanka and Murdoch University, Western Australia.

McNeil D. L. (1982). Variations in ability of Rhizobium japonicum strains to nodulate soybeans and maintain fixation in the presence of nitrate. Applied and Environmental Microbiology 44:647-652.

DOI: https://doi.org/10.1128/aem.44.3.647-652.1982

Ojiem J. O., Franke A. C., Vanlauwe B., De Ridder N., \& Giller K. E. (2014). Benefits of legume-maize rotations: Assessing the impact of diversity on the productivity of smallholders in Western Kenya. Field Crops Research 168: 75-85.

DOI: https://doi.org/10.1016/j.fcr.2014.08.004

Peoples M.B., Herridge D.F. \& Ladha J.K.(2002). Biological nitrogen fixation: An efficient source of nitrogen for sustainable agricultural production. Plant and Soil 174: $3-28$.

DOI: https://doi.org/10.1007/BF00032239

Rajapakse S., Mitrakrishnan C.S. \& Selvarajah M. (2016). Chronic kidney disease of unknown etiology in Sri Lanka. International Journal of Occupational and Environmental Health 22(3):259-264.

DOI: https://doi.org/10.1080/10773525.2016.1203097 
Rengel Z. (2002). Breeding for better symbiosis. Plant and Soil 245: 147-162.

DOI: https://doi.org/10.1023/A:1020692715291

Rurangwa E., Vanlauwe B. \& Giller K. E. (2018). Benefits of inoculation, $\mathrm{P}$ fertilizer and manure on yields of common bean and soybean also increase yield of subsequent maize. Agriculture, Ecosystems and Environment 261: 219-229. DOI: https://doi.org/10.1016/j.agee.2017.08.015

Santos M.S., Nogueira M.A. \& Hungria M. (2019). Microbial inoculants: reviewing the past, discussing the present and previewing an outstanding future for the use of beneficial bacteria in agriculture. AMB Express 9(1): 205. DOI: https://doi.org/10.1186/s13568-019-0932-0

Schwinghamer E. A. \& Brockwell J. (1978). Competitive advantage of bacteriocin- and phage-producing strains of Rhizobium trifohi in mixed culture. Soil Biology and Biochemistry 10:383-387.

DOI: https://doi.org/10.1016/0038-0717(78)90062-7

Somasegaran P. \& Ben Bohlool B. (1990). Single-Strain versus multi strain inoculation: effect of soil mineral $\mathrm{N}$ availability on rhizobial strain effectiveness and competition for nodulation on chick-pea, soybean, and dry bean. Applied and Environmental Microbiology 56(11): 3298-3303.

DOI: https://doi.org/10.1128/aem.56.11.3298-3303.1990

Sutherland J.M., Odee D.W., Muluvi G.M., McInroy S.G. \& Patel A. (2000). Single and multi-strain rhizobial inoculation of African acacias in nursery conditions. Soil Biology and Biochemistry 32(3): 323-333.

DOI: https://doi.org/10.1016/S0038-0717(99)00157-1

Tewari S. \& Arora N.K. (2014). Talc based exopolysaccharides formulation enhancing growth and production of Hellianthus annuus under saline conditions. Cellular and Molecular Biology 60(5):73-81.

Thompson J. A. (1980). Production and quality control of legume inoculants. In: Methods for Evaluating Biological Nitrogen Fixation (ed. F. J. Bergersen), pp. 489-533. John Wiley \& Sons, Inc., New York USA.

Xuan X., Chunmei M., Shoukun D., Yao X. \& Zhenping G. (2017). Effects of nitrogen concentrations on nodulation and nitrogenase activity in dual root systems of soybean plants. Soil Science and Plant Nutrition 63(5): 470482.

DOI: 10.1080/00380768.2017.1370960.

Zablotowicz R. M., Tipping E.M., Lifshitz R.\& Kloepper J. W. (1991). Plant growth promotion mediated by bacterial rhizosphere colonizers. In: The rhizosphere and plant growth, pp. 315-326. Springer, Dordrecht.

DOI: https://doi.org/10.1007/978-94-011-3336-4_70

Zahran H.H. (2001). Rhizobia from wild legumes: diversity, taxonomy, ecology, nitrogen fixation and biotechnology. Journal of Biotechnology 91(2): 143-153.

DOI: https://doi.org/10.1016/S0168-1656(01)00342-X 
Supplementary data

Supplementary Table 1: Plants visual rate, nodule number, nodule dry weight, shoot dry weight and root dry weight of $V$. mungo

\begin{tabular}{lccccc}
\hline STRAIN & AVR & ANN & AND & ASD & ARD \\
\hline M5VD1K7 & 8.00 & $5.9701^{\mathrm{c}}$ & $0.0097^{\mathrm{bc}}$ & $0.6560^{\mathrm{a}}$ & $0.0937^{\mathrm{a}}$ \\
M5VD1 & 8.00 & $11.6667^{\mathrm{b}}$ & $0.0133^{\mathrm{b}}$ & $0.6939^{\mathrm{a}}$ & $0.0991^{\mathrm{a}}$ \\
M5K7 & 9.00 & $18.3333^{\mathrm{a}}$ & $0.0198^{\mathrm{a}}$ & $0.7605^{\mathrm{a}}$ & $0.1087^{\mathrm{a}}$ \\
VD1K7 & 8.00 & $8.0000^{\mathrm{bc}}$ & $0.0122^{\mathrm{b}}$ & $0.6550^{\mathrm{a}}$ & $0.0936^{\mathrm{a}}$ \\
M5 & 8.00 & $4.2812^{\mathrm{c}}$ & $0.0095^{\mathrm{bc}}$ & $0.6433^{\mathrm{a}}$ & $0.0919^{\mathrm{a}}$ \\
VD1 & 8.00 & $11.7252^{\mathrm{b}}$ & $0.0130^{\mathrm{b}}$ & $0.6711^{\mathrm{a}}$ & $0.0958^{\mathrm{a}}$ \\
K7 & 8.00 & $9.3521 \mathrm{~b}^{\mathrm{c}}$ & $0.1200^{\mathrm{b}}$ & $0.6769^{\mathrm{a}}$ & $0.0967^{\mathrm{a}}$ \\
N+ & 8.00 & $0.0000^{\mathrm{d}}$ & $0.0000^{\mathrm{d}}$ & $0.6645^{\mathrm{a}}$ & $0.0949^{\mathrm{a}}$ \\
N- & 7.00 & $0.0000^{\mathrm{d}}$ & $0.0000^{\mathrm{d}}$ & $0.4668^{\mathrm{b}}$ & $0.0667^{\mathrm{b}}$ \\
\hline
\end{tabular}

$\mathrm{AVR}=$ average visual rate, $\mathrm{ANN}=$ average no. nodules/plant, $\mathrm{AND}=$ average nodule dry weight $(\mathrm{g} / \mathrm{plant})$, $\mathrm{ASD}=$ average shoot dry weight $(\mathrm{g} / \mathrm{plant}), \mathrm{ARD}=$ average Root dry weight ( $\mathrm{g} / \mathrm{plant})$. Values in the same column followed by the same letter are not significantly different at $5 \%$ probability level.

Supplementary Table 1: Plants visual rate, nodule number, nodule dry weight, shoot dry weight and root dry weight of $V$. radiata

\begin{tabular}{lccccc}
\hline STRAIN & AVR & ANN & AND & ASD & ARD \\
\hline C10M6K7 & 8 & $12.8333^{\mathrm{c}}$ & $0.0133^{\mathrm{b}}$ & $0.6571^{\mathrm{b}}$ & $0.0939^{\mathrm{b}}$ \\
C10M6 & 8 & $6.4721^{\mathrm{d}}$ & $0.0073^{\mathrm{c}}$ & $0.5439^{\mathrm{bc}}$ & $0.0777^{\mathrm{bc}}$ \\
C10K7 & 8.5 & $17.3562^{\mathrm{b}}$ & $0.0153^{\mathrm{b}}$ & $0.6972^{\mathrm{b}}$ & $0.0996^{\mathrm{b}}$ \\
M6K7 & 8 & $13.2542^{\mathrm{c}}$ & $0.0134^{\mathrm{b}}$ & $0.5545^{\mathrm{bc}}$ & $0.0794^{\mathrm{bc}}$ \\
C10 & 9 & $21.0000^{\mathrm{a}}$ & $0.0196^{\mathrm{a}}$ & $0.8993^{\mathrm{a}}$ & $0.1285^{\mathrm{a}}$ \\
M6 & 8 & $6.7522^{\mathrm{d}}$ & $0.0075^{\mathrm{c}}$ & $0.6280^{\mathrm{b}}$ & $0.0897^{\mathrm{b}}$ \\
K7 & 8.5 & $16.6452^{\mathrm{b}}$ & $0.0169^{\mathrm{ab}}$ & $0.7841^{\mathrm{ab}}$ & $0.1120^{\mathrm{ab}}$ \\
N+ & 8 & $0.0000^{\mathrm{c}}$ & $0.0000^{\mathrm{d}}$ & $0.6707^{\mathrm{b}}$ & $0.0958^{\mathrm{b}}$ \\
N- & 7 & $0.0000^{\mathrm{c}}$ & $0.0000^{\mathrm{d}}$ & $0.5135^{\mathrm{bc}}$ & $0.0734^{\mathrm{bc}}$ \\
\hline
\end{tabular}

$\mathrm{AVR}=$ average visual rate, $\mathrm{ANN}=$ average number of nodules, $\mathrm{AND}=$ average nodule dry weight $(\mathrm{g} / \mathrm{plant})$, $\mathrm{ASH}=$ average shoot height $(\mathrm{cm}), \mathrm{ARL}=$ average root length $(\mathrm{cm}), \mathrm{ASD}=$ average shoot dry weight $(\mathrm{g} / \mathrm{plant})$, $\mathrm{ARD}=$ average root dry weight (g/plant). Values in the same column followed by the same letter are not significantly different at $5 \%$ probability level.

Supplementary Table 3: Plants visual rate, nodule number, nodule dry weight, shoot dry weight and root dry weight of G. $\max$

\begin{tabular}{lccccc}
\hline STRAIN & AVR & ANN & AND & ASD & ARD \\
\hline C8VD1K7 & 8 & $5.7210^{\mathrm{d}}$ & $0.0062^{\mathrm{d}}$ & $0.8856^{\mathrm{b}}$ & $0.1265^{\mathrm{b}}$ \\
C8K7 & 7.5 & $18.4572^{\mathrm{b}}$ & $0.0162^{\mathrm{b}}$ & $1.0896^{\mathrm{b}}$ & $0.1557^{\mathrm{b}}$ \\
C8VD1 & 7.5 & $6.0000^{\mathrm{d}}$ & $0.0078^{\mathrm{d}}$ & $0.9965^{\mathrm{b}}$ & $0.1425^{\mathrm{b}}$ \\
VD1K7 & 9 & $27.4251^{\mathrm{a}}$ & $0.0211^{\mathrm{a}}$ & $1.4262^{\mathrm{a}}$ & $0.2038^{\mathrm{a}}$ \\
C8 & 8 & $16.8521^{\mathrm{bc}}$ & $0.0129^{\mathrm{bc}}$ & $0.9551^{\mathrm{b}}$ & $0.1364^{\mathrm{b}}$ \\
VD1 & 8 & $19.7542^{\mathrm{b}}$ & $0.0139^{\mathrm{bc}}$ & $1.1152^{\mathrm{b}}$ & $0.1593^{\mathrm{b}}$ \\
K7 & 8 & $13.3342^{\mathrm{c}}$ & $0.0132^{\mathrm{bc}}$ & $1.0895^{\mathrm{b}}$ & $0.1556^{\mathrm{b}}$ \\
$\mathrm{N}+$ & 8 & $0.0000^{\mathrm{e}}$ & $0.0000^{\mathrm{e}}$ & $0.9630^{\mathrm{b}}$ & $0.1376^{\mathrm{b}}$ \\
$\mathrm{N}-$ & 6 & $0.0000^{\mathrm{e}}$ & $0.0000^{\mathrm{e}}$ & $0.8350^{\mathrm{bc}}$ & $0.1193^{\mathrm{b}}$ \\
\hline
\end{tabular}

$\mathrm{AVR}=$ average visual rate, $\mathrm{ANN}=$ average number of nodules, $\mathrm{AND}=$ average nodule dry weight $(\mathrm{g} / \mathrm{plant})$, $\mathrm{ASH}=$ average shoot height $(\mathrm{cm}), \quad \mathrm{ARL}=$ average root length $(\mathrm{cm}), \mathrm{ASD}=$ average shoot dry weight $(\mathrm{g} /$ plant), $\mathrm{ARD}=$ average root dry weight (g/plant). Values in the same column followed by the same letter are not significantly different at $5 \%$ probability level. 


\section{Field experiment}

Supplementary Table 4: Plants visual rate, nodule number, nodule dry weight, shoot dry weight and root dry weight of $V$. mungo

\begin{tabular}{lccccc}
\hline STRAIN & AVR & ANN & AND & ASD & ARD \\
\hline M5VD1K7 & 8 & $51.00^{\mathrm{a}}$ & $0.1386^{\mathrm{a}}$ & $11.6545^{\mathrm{bc}}$ & $1.6649^{\mathrm{ab}}$ \\
M5VD1 & 8 & $47.33^{\mathrm{ab}}$ & $0.1111^{\mathrm{b}}$ & $13.0484^{\mathrm{b}}$ & $1.8641^{\mathrm{ab}}$ \\
M5K7 & 9 & $29.29^{\mathrm{c}}$ & $0.0878^{\mathrm{c}}$ & $15.7730^{\mathrm{a}}$ & $2.2533^{\mathrm{a}}$ \\
VD1K7 & 8 & $38.88^{\mathrm{b}}$ & $0.0857^{\mathrm{c}}$ & $12.7199^{\mathrm{b}}$ & $1.8171^{\mathrm{ab}}$ \\
M5 & 8 & $33.50^{\mathrm{c}}$ & $0.0806^{\mathrm{c}}$ & $12.5093^{\mathrm{b}}$ & $1.7871^{\mathrm{ab}}$ \\
VD1 & 9 & $46.22^{\mathrm{ab}}$ & $0.0904^{\mathrm{c}}$ & $15.2458^{\mathrm{ab}}$ & $2.1779^{\mathrm{a}}$ \\
K7 & 8 & $48.67^{\mathrm{a}}$ & $0.0901^{\mathrm{c}}$ & $12.7244^{\mathrm{b}}$ & $1.8177^{\mathrm{ab}}$ \\
N+ & 8 & $42.86^{\mathrm{b}}$ & $0.0803^{\mathrm{c}}$ & $11.5312^{\mathrm{bc}}$ & $1.6473^{\mathrm{ab}}$ \\
N- & 8 & $39.67^{\mathrm{b}}$ & $0.0700^{\mathrm{c}}$ & $11.6473^{\mathrm{bc}}$ & $1.6341^{\mathrm{ab}}$ \\
\hline
\end{tabular}

AVR $=$ average visual rate, ANN = average number of nodules, AND = average nodule dry weight $(\mathrm{g} / \mathrm{plant}), \mathrm{ASH}=$ average shoot height $(\mathrm{cm})$, $\mathrm{ARL}=$ average root length $(\mathrm{cm}), \mathrm{ASD}=$ average shoot dry weight $(\mathrm{g} / \mathrm{plant}), \mathrm{ARD}=$ average root dry weight $(\mathrm{g} / \mathrm{plant})$ Values in the same column followed by the same letter are not significantly different at $5 \%$ probability level.

Supplementary Table 5: Plants visual rate, nodule number, nodule dry weight, shoot dry weight and Root dry weight of $V$. radiata

\begin{tabular}{lccccc}
\hline STRAIN & AVR & ANN & AND & ASD & ARD \\
\hline C10M6K7 & 9 & $47.5^{\mathrm{a}}$ & $0.0580^{\mathrm{a}}$ & $4.2858^{\mathrm{ab}}$ & $0.6123^{\mathrm{ab}}$ \\
C10M6 & 7 & $44.33^{\mathrm{ab}}$ & $0.0378^{\mathrm{bc}}$ & $3.2323^{\mathrm{b}}$ & $0.4618^{\mathrm{b}}$ \\
C10K7 & 9 & $39.21^{\mathrm{b}}$ & $0.0465^{\mathrm{b}}$ & $4.4582^{\mathrm{a}}$ & $0.6369^{\mathrm{a}}$ \\
M6K7 & 9 & $43.16^{\mathrm{ab}}$ & $0.0443^{\mathrm{b}}$ & $3.8511^{\mathrm{b}}$ & $0.5502^{\mathrm{b}}$ \\
C10 & 8 & $40.67^{\mathrm{b}}$ & $0.0331^{\mathrm{c}}$ & $3.4288^{\mathrm{b}}$ & $0.4898^{\mathrm{b}}$ \\
M6 & 9 & $40.89^{\mathrm{b}}$ & $0.0413^{\mathrm{b}}$ & $3.7989^{\mathrm{b}}$ & $0.5427^{\mathrm{b}}$ \\
K7 & 8.5 & $39.56^{\mathrm{b}}$ & $0.0489^{\mathrm{b}}$ & $4.1168^{\mathrm{ab}}$ & $0.5881^{\mathrm{b}}$ \\
$\mathrm{N}+$ & 8 & $34.57^{\mathrm{bc}}$ & $0.0283^{\mathrm{c}}$ & $3.6981^{\mathrm{b}}$ & $0.5283^{\mathrm{b}}$ \\
$\mathrm{N}-$ & 7.5 & $29.75^{\mathrm{c}}$ & $0.0277^{\mathrm{c}}$ & $3.2204^{\mathrm{b}}$ & $0.4601^{\mathrm{b}}$ \\
\hline
\end{tabular}

$\mathrm{AVR}=$ average visual rate, $\mathrm{ANN}=$ average number of nodules, AND = average nodule dry weight $(\mathrm{g} / \mathrm{plant})$, ASH $=$ average shoot height $(\mathrm{cm})$, $\mathrm{ARL}=$ average root length $(\mathrm{cm}), \mathrm{ASD}=$ average shoot dry weight $(\mathrm{g} / \mathrm{plant}), \mathrm{ARD}=$ average root dry weight $(\mathrm{g} / \mathrm{plant})$. Values in the same column followed by the same letter are not significantly different at $5 \%$ probability level.

Supplementary Table 6: Plants visual rate, nodule number, nodule dry weight, shoot dry weight and root dry weight of G. $\max$

\begin{tabular}{lccccc}
\hline STRAIN & AVR & ANN & AND & ASD & ARD \\
\hline C8VD1K7 & 7.5 & $50.71^{\mathrm{b}}$ & $0.2462^{\mathrm{c}}$ & $6.8668^{\mathrm{b}}$ & $0.9810^{\mathrm{b}}$ \\
C8K7 & 9 & $53.71^{\mathrm{b}}$ & $0.3927^{\mathrm{ab}}$ & $8.9506^{\mathrm{a}}$ & $1.2787^{\mathrm{a}}$ \\
C8VD1 & 7 & $53.63^{\mathrm{b}}$ & $0.2254^{\mathrm{c}}$ & $6.6441^{\mathrm{b}}$ & $0.9492^{\mathrm{b}}$ \\
VD1K7 & 8 & $73.00^{\mathrm{a}}$ & $0.4262^{\mathrm{a}}$ & $7.2959^{\mathrm{b}}$ & $1.0423^{\mathrm{b}}$ \\
C8 & 8 & $55.38^{\mathrm{b}}$ & $0.3117^{\mathrm{b}}$ & $6.9658^{\mathrm{b}}$ & $0.9951^{\mathrm{b}}$ \\
VD1 & 8.5 & $59.57^{\mathrm{b}}$ & $0.2865^{\mathrm{b}}$ & $7.2616^{\mathrm{b}}$ & $1.0374^{\mathrm{b}}$ \\
K7 & 8 & $56.33^{\mathrm{b}}$ & $0.3152^{\mathrm{b}}$ & $7.2634^{\mathrm{b}}$ & $1.0376^{\mathrm{b}}$ \\
N+ & 8 & $43.43^{\mathrm{c}}$ & $0.2205^{\mathrm{c}}$ & $6.8877^{\mathrm{b}}$ & $0.9840^{\mathrm{b}}$ \\
N- & 7 & $30.00^{\mathrm{cd}}$ & $0.2065^{\mathrm{c}}$ & $6.4960^{\mathrm{b}}$ & $0.9280^{\mathrm{b}}$ \\
\hline
\end{tabular}

AVR $=$ average visual rate, ANN = average number of nodules, AND = average nodule dry weight $(\mathrm{g} / \mathrm{plant})$, ASH $=$ average shoot height $(\mathrm{cm})$, $\mathrm{ARL}=$ average root length $(\mathrm{cm}), \mathrm{ASD}=$ average shoot dry weight $(\mathrm{g} / \mathrm{plant}), \mathrm{ARD}=$ average root dry weight $(\mathrm{g} / \mathrm{plant})$. Values in the same column followed by the same letter are not significantly different at $5 \%$ probability level. 